\title{
POLIMER HULLADÉKOK PIROLÍZISÉVEL NYERT SZILÁRD MARADÉKOK TOVÁBBI HASZNOSÍTHATÓSÁGA
}

\section{UTILIZATION OF SOLID RESIDUE FROM WASTE PYROLYSIS}

\author{
Sója János ${ }^{1}$, Fogarasi Zsolt Miklós ${ }^{2}$, Miskolczi Norbert ${ }^{3}$ \\ ${ }^{I}$ Pannon Egyetem, Mérnöki Kar, MOL Ásványolaj- és Széntechnológiai Intézeti Tan- \\ szék, Magyarország, 8200 Veszprém, Egyetem utca 10.; Telefon: +36-88-624- \\ 000P6170,e-mail: sojajanos@almos.uni-pannon.hu \\ ${ }^{2}$ MOL LUB Kft., Magyarország, 2931 Almásfüzitö, Fö út 21.; Telefon: +36-70-776- \\ 0099,e-mail: zsfogarasi@mol.hu \\ ${ }^{3}$ Pannon Egyetem, Mérnöki Kar, MOL Ásványolaj- és Széntechnológiai Intézeti Tan- \\ szék, Magyarország, 8200 Veszprém, Egyetem utca 10.; Telefon: +36-88-624-410, \\ e-mail:mnorbert@almos.uni-pannon.hu
}

\begin{abstract}
With the chemical recycling of plastic waste (pyrolysis) we can obtain more valuable products. These products are suitable for generating energy or producing chemical raw materials. However the utilization of solid residue is still unsolved. In our experiment we pyrolysed municipal solid waste at $500{ }^{\circ} \mathrm{C}$. We examined that if the obtained residue, treated with activation agent, or without treatment, is suitable for improving certain properties of base oil.
\end{abstract}

Keywords: pyrolysis, polymer waste, char

\section{Összefoglalás}

A mủanyag hulladékok kémiai újrahasznosításával (pirolízissel) értékesebb termékek állíthatók elö, melyek alkalmasak energia vagy vegyipari alapanyagok előállítására. Azonban a keletkező kokszos maradék hasznosítása még nem megoldott. Kísérletünk során települési szilárd hulladékot pirolizáltunk $500{ }^{\circ} \mathrm{C}$-on és azt vizsgáltuk, hogy az így előállított maradék kezelés nélkül, illetve aktiváló ágensekkel való kezelés után alkalmas-e egy alapolaj elegy bizonyos tulajdonságainak javítására.

Kulcsszavak: pirolizis, polimer hulladék, szén

\section{Bevezetés}

A hulladékokból történő energia előállítás napjaink egyik fontos kutatási területe. A hulladékokból pirolízissel értékesebb termékek állíthatók elö, mely során maradékként nagy széntartalmú koksz is kelet- kezik [1], A kokszos maradék további hasznosítása még nem megoldott.

Az aktív szenet, mely napjaink egyik legelterjedtebb adszorbense hagyományos úton kőszénből állítják elő, ám környezetvédelmi és gazdasági megfontolásokból előtérbe került az alternatív alapanyagokból történő elöállítás lehetősége is. Az egyik 
ilyen lehetőség, a hulladék polimerek szilárd pirolízis termékeinek felületaktív anyagként történő alkalmazása [2-3].

Kísérleti munkánk célja annak vizsgálata volt, hogy a polimer hulladékok pirolízise során keletkező kokszos szilárd maradék alkalmas lehet-e egy kenőolaj célú alapolaj elegy bizonyos tulajdonságainak javítására.

\section{Felhasznált anyagok}

Alapanyagként települési szilárd hulladékot használtunk, mely föleg poliolefineket tartalmazott. Emellett pedig $11 \%$ poli-vinil-kloridot és polietiléntereftalátot is.

\section{Mérési módszer}

Az alapanyagból két lépésben nyertünk aktivált szenet: először pirolizáltuk azt, majd a szilárd frakciót különböző módon aktiváltuk.

A termikus pirolízist egy 2 liter térfogatú reaktorban, inert (nitrogén) atmoszférában, légköri nyomáson és $500^{\circ} \mathrm{C}$-on végeztük. A gázokból a pirolízisolajat egy vizes hütőben $20^{\circ} \mathrm{C}$-on lekondenzáltattuk, majd egy fázisszeparátorban választottuk el a gázoktól, melynek mennyiségét egy gázáramlásmérővel határoztuk meg. A termékösszetétel a következő volt: $3 \%$ gáz, $9 \%$ szilárd maradék és $88 \%$ olaj. Az alkalmazott berendezést az 1. ábra szemlélteti.

A kokszos maradék rendelkezett bizonyos fokú pórusos szerkezettel, melynek szorpciós tulajdonságait kémiai úton szerettük volna fokozni. Aktiváló ágensként nátrium-hidroxidot és foszforsavat választottunk. A müvelet egyes paramétereit az 1. táblázat tartalmazza. Az aktiválási folyamatot atmoszférikus nyomáson, vizes közegben, $100-110^{\circ} \mathrm{C}$-os hőmérséklettartományban valósítottuk meg. Egy óra elteltével a szenet leszürtük, desztillált vízzel többször átmostuk, majd a nedvességtartalmát szárítószekrényben 105 C-on eltávolítottuk.

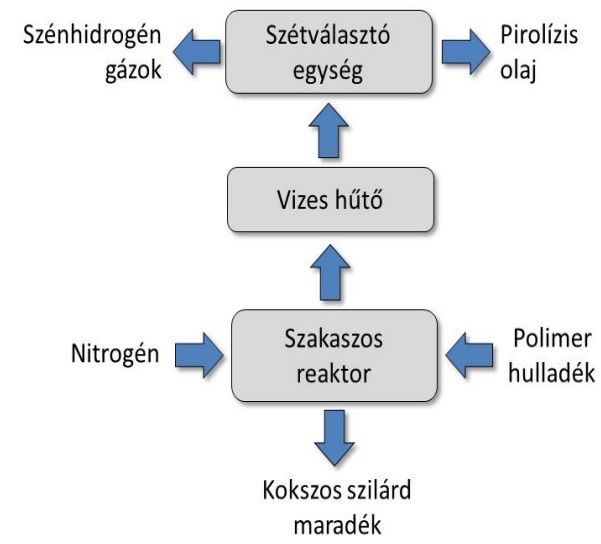

1. ábra. A pirolizis berendezése

1. táblázat. Az aktiválás körülményei

\begin{tabular}{|c|c|}
\hline Paraméter & Érték \\
\hline Hômérséklet & $100-110{ }^{\circ} \mathrm{C}$ \\
\hline Nyomás & $1 \mathrm{~atm}$ \\
\hline Aktiválási idő & 1 óra \\
\hline $\begin{array}{c}\text { Alapanyag kon- } \\
\text { centráció }\end{array}$ & $5 \mathrm{~m} / \mathrm{m} \%$ \\
\hline Aktiváló ágens & \\
\hline $\begin{array}{c}\text { NaOH koncent- } \\
\text { ráció }\end{array}$ & $5 ; 10 ; 20 ; 30 \mathrm{~m} / \mathrm{m} \%$ \\
\hline $\begin{array}{c}\mathbf{H}_{3} \mathbf{P O}_{4} \text { koncent- } \\
\text { ráció }\end{array}$ & $\begin{array}{c}10 ; 30 ; 50 ; 70 \\
\mathrm{~m} / \mathrm{m} \%\end{array}$ \\
\hline
\end{tabular}

Az így elöállított szén hatását egy adott turbinaolaj-alapolaj elegy levegőelváló képességén keresztül vizsgáltuk. Ha ez az érték túl nagy, a hidraulikus rendszerben problémák adódhatnak. Másodsorban nagyon fontos a víztôl való elválási hajlam, ugyanis annak jelenléte a rendszerben korróziót, mikroorganikus szennyeződést vagy habzást okozhat.

A levegőelváló képesség mértékegysége az a percben kifejezett idő, ami ahhoz szükséges, hogy az olajban diszpergálódott levegő az elfogadható mennyiségre ( $2 \mathrm{~V} / \mathrm{V} \%)$ csökkenjen. A mérést úgy végeztük, hogy $50{ }^{\circ} \mathrm{C}$-ra melegítettük az olajat, majd 7 percen keresztül ugyanilyen hömérsékletủ sürített levegöt fúvattunk át rajta 0,2 bar túl- 
nyomással. Az eltelt idő függvényében mértük a sürüségét, aminek az időbeli változása a minta levegötartalmára enged következtetni.

A víztől való elválási hajlam mérésének elve az, hogy $40 \mathrm{~cm}^{3}$ olajat és ugyanennyi vizet $54{ }^{\circ} \mathrm{C}$-on, 5 percen keresztül 1500 r/perc fordulatszámú keverővel egy 100 $\mathrm{cm}^{3}$-es mérőhengerben elegyítünk, majd a fázisok elválási idejét regisztráljuk. A kialakult emulziónak (mely ideális esetben nem stabil) a felbomlási idejét mértük, és miután az megtörtént, az elkülönült fázisok térfogatát feljegyeztük a következő módon: olaj:víz:emulzió/szétválási idő.

\section{Mérési eredmények és értékelé- sük}

A különböző módon kezelt szeneken szürt kenőolajok $50^{\circ} \mathrm{C}$-on mért levegőelváló képességét és $54^{\circ} \mathrm{C}$-on mért víztől való elválási hajlamát mértük. Referenciaként a szüretlen alapolaj elegyre ezek az értékek sorrendben 7 perc és $40 \mathrm{~cm}^{3}: 40 \mathrm{~cm}^{3}: 0$ $\mathrm{cm}^{3} / 5$ perc voltak.

A hulladékokból előállított kezeletlen szénszármazékkal derítést végeztünk a vizsgálandó olaj mintán, majd a különböző töménységű foszforsavas és nátriumhidroxidos kezelésnek alávetett szenekkel is megszürtük azt. A víztől való elválási hajlam értékeit a 2. táblázat tartalmazza.

A víztől való elválási hajlam ugyan megfelelő volt, azonban a szétválási idő minden esetben többszöröse lett a szüretlen alapolajénak, azaz romlott a referenciához képest.

A 2. ábra az $50{ }^{\circ} \mathrm{C}$-on mért levegőelváló képesség változását mutatja a foszforsavval kezelt szürőközegek esetében a vegyszer koncentrációjának függvényében, míg a 3. ábra ugyanezt mutatja a nátriumhidroxiddal kezelt esetekben.
2. táblázat. $A$ viztöl való elválási hajlam

\begin{tabular}{|c|c|c|c|}
\hline Minta & $\begin{array}{c}\text { Víztől } \\
\text { való } \\
\text { elválási } \\
\text { hajlam }\end{array}$ & Minta & $\begin{array}{c}\text { Víztől } \\
\text { való } \\
\text { elválási } \\
\text { hajlam }\end{array}$ \\
\hline $\begin{array}{c}\text { Alapolaj } \\
\text { elegy }\end{array}$ & $\begin{array}{c}40-40- \\
0 / 5\end{array}$ & $\begin{array}{c}\text { Alapolaj } \\
\text { elegy }\end{array}$ & $\begin{array}{c}40-40- \\
0 / 5\end{array}$ \\
\hline $\begin{array}{l}\text { Kezeletlen } \\
\text { szénszárm } \\
\text { azék }\end{array}$ & $\begin{array}{c}40-39- \\
1 / 20\end{array}$ & $\begin{array}{c}\text { Kezeletlen } \\
\text { szénszárm } \\
\text { azék }\end{array}$ & $\begin{array}{c}40-39- \\
1 / 20\end{array}$ \\
\hline $\begin{array}{c}10 \%-0 S \\
\mathrm{H}_{3} \mathrm{PO}_{4}\end{array}$ & $\begin{array}{c}41-38- \\
1 / 50\end{array}$ & $\begin{array}{l}5 \%-0 s \\
\mathrm{NaOH}\end{array}$ & $\begin{array}{c}41-36- \\
3 / 30\end{array}$ \\
\hline $\begin{array}{c}30 \%-0 \mathrm{~S} \\
\mathrm{H}_{3} \mathrm{PO}_{4}\end{array}$ & $\begin{array}{c}43-37- \\
0 / 40\end{array}$ & $\begin{array}{c}10 \%-0 S \\
\mathrm{NaOH}\end{array}$ & $\begin{array}{c}42-38- \\
0 / 30\end{array}$ \\
\hline $\begin{array}{c}50 \%-0 S \\
\mathrm{H}_{3} \mathrm{PO}_{4} \\
\end{array}$ & $\begin{array}{c}40-40- \\
0 / 20 \\
\end{array}$ & $\begin{array}{c}20 \%-0 S \\
\mathrm{NaOH} \\
\end{array}$ & $\begin{array}{c}40-37- \\
3 / 30 \\
\end{array}$ \\
\hline $\begin{array}{l}70 \%-0 S \\
\mathrm{H}_{3} \mathrm{PO}_{4}\end{array}$ & $\begin{array}{c}39-37- \\
4 / 20\end{array}$ & $\begin{array}{c}\text { 30\%-os } \\
\mathrm{NaOH}\end{array}$ & $\begin{array}{c}42-38- \\
0 / 30\end{array}$ \\
\hline
\end{tabular}

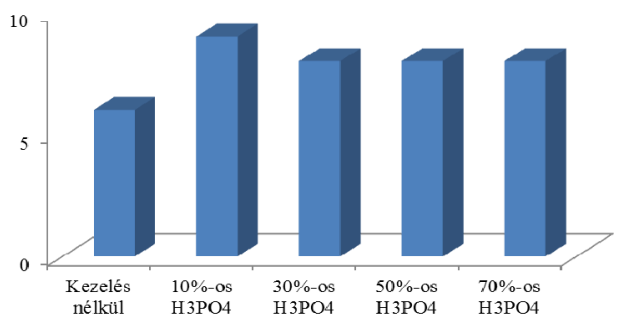

2. ábra. $A z 50{ }^{\circ} \mathrm{C}$-on mért levegöelváló képesség változása a szürőközeg függvényében foszforsavas kezelés esetén (az alapolajra ez az érték 7 perc)

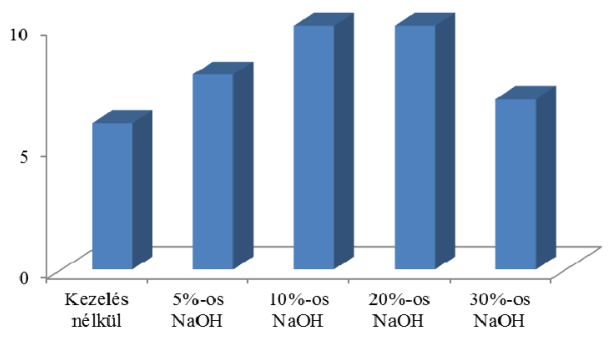

3. ábra. $\mathrm{Az} 50^{\circ} \mathrm{C}$-on mért levegöelváló képesség változása a szüröközeg függvényében nátrium-hidroxidos kezelés esetén (az alapolajra ez az érték 7 perc) 
Az eredmények alapján kijelenthetö, hogy a hulladék müanyagból előállított szilárd maradékok rendelkeztek bizonyos mértékü porozitással a vegyszeres kezelések elött, ugyanis az a minta levegőelváló képességet csökkentette az alapolajhoz képest. A pórusos szerkezet valószínűleg a pirolízis során a mátrixból kiszakadó molekula fragmentumok mozgása révén jött létre.

A foszforsavas kezelés hatására minden esetben megnőtt a levegőelváló képesség, azaz romlott az olaj ezen jellemzője. Ennek az a magyarázata, hogy az enyhébb körülmények között stabil pórusos szerkezet a savas kezelés hatására megváltozott. Hasonló hatást értünk el a másik kezeléssel is. Az 5 és $10 \%$-os nátrium-hidroxid oldatok rontották a levegőelváló képességet, azonban tovább növelve a lúg koncentrációját elkezdett csökkenni annak értéke. $30 \%$ $\mathrm{NaOH}$ koncentrációnál már a referencia értéket produkálta a minta.

\section{Szakirodalmi hivatkozások}

[1] Hajdary, J., et al.: Pyrolysis of automobile shredder residue in a laboratory scale screw type reactor. Journal of Environmental Chemical Engineering, 4, 2016, 965-972.

[2] Kartel, M.T. et al.: Preparation of porous carbons by chemical activation of polyethylene-terephthalate. Carbon, 44 (5), 2006, 1019-1022.

[3] Hayashi, Y. et al.: Preparation and characterization of high-specific-surfacearea activated carbons from $\mathrm{K}_{2} \mathrm{CO}_{3}$-treated waste polyurethane. Journal of Colloid and Interface Science, 281 (2), 2005, 437-443.

\section{Köszönetnyilvánítás}

A szerzők köszönetüket fejezik ki a Nemzeti Kutatási és Innovációs Hivatal, Magyar-indiai (KTIA-DST) $\mathrm{K}+\mathrm{F}+\mathrm{I}$ együttmüködési program (TÉT_13_DST) keretében nyújtott támogatásért (TÉT_13_DST-1-2014-0003). 